\title{
Evidence of genetic heterogeneity in Huntington's chorea
}

\author{
D. C. WALLACE ${ }^{1}$ AND A. C. HALL \\ From the Queensland Institute of Medical Research and the Department of Psychology, The University \\ of Newcastle, Newcastle, New South Wales, Australia
}

SUMMARY In an extensive study of Huntington's chorea in Queensland evidence was found to support an old observation that the magnitude of the variation in the symptom complex of the disease between different families is sufficient to suggest that there may be more than one form of Huntington's chorea allele present in the community. Analysis of data concerning age at onset indicates that at least two separate forms of the disorder may exist.

It is generally accepted that Huntington's chorea is a single entity (McKusick, 1971). Reed and Chandler (1958) considered that the evidence from the data obtained during their survey in Michigan favoured the hypothesis that a single mutant gene is responsible in all cases. Bruyn (1968) in his monumental review accepts that there are three forms of the disorder: the classical form, a juvenile form, and the form he describes as the Westphal variant. However, he describes these variants as occurring in sibships where other cases have shown the features of the more common classical form of the disease, thus indicating a single mutant gene with varying expression in different individuals. Myrianthopoulos (1966) accepts that Huntington's chorea of childhood is a separate entity, but notes that these clinically peculiar cases are children born to choreic parents in families with Huntington's chorea and hence by implication represent the varying expressivity of the mutant allele.

Yet astute observers long ago recognized that the disease tended to run a different course in different families. Davenport and Muncey (1916) coined the term 'biotype' to describe the various strains as they occur in separate families. The term was created on clinical impression alone, and later workers, notably Chandler, Reed, and De Jong (1960) failed to confirm this impression in their Michigan study. Yet the impression re-

1 Present address: The Royal Newcastle Hospital, Newcastle, New South Wales 2300, Australia. mains, particularly among clinical workers (Bittenbender and Quadfasel, 1962; MüllerKüppers and Stenzel, 1963) that familial variations in symptom complexes do occur and may have a basis in the genetic entity giving rise to this disease. It is the purpose of this communication to re-examine this problem in the light of data obtained during an extensive clinical and epidemiological survey of Huntington's chorea in Queensland.

\section{METHOD OF STUDY}

During the years 1969 and 1970 an attempt was made to locate and interview every case of Huntington's chorea in Queensland, Australia, to obtain details of their family trees and to classify all living members of the families at risk. Notifications of families were obtained from many sources, and multiple ascertainment of kindreds and even of patients was the rule, rather than the exception, as was intended and which suggests a very complete ascertainment of all families with the disorder. Dr. Neville Parker's (1958) detailed and extensive pedigrees were obtained, the members of these families were checked, and the pedigrees were brought up to date. A personal approach was made to every medical practitioner specializing in a field which it was judged might include some cases of Huntington's chorea. In this way every psychiatrist, neurologist, neurosurgeon, and geriatrician practising in Queensland was approached for information concerning cases suffering from the disease. An approach was made to all 789 
General Practitioners for information on families or cases of the disease, and a personal search of the wards of the state's psychiatric institutions and individual approaches to the medical and nursing staff of each hospital, nursing home, or organization concerned in any way with the care of patients in the State of Queensland were made to locate further cases.

Each of the patients located, and each of the family members resident in Queensland who could have been at risk of developing the disease was examined personally as far as this was possible, and, in addition, extensive interstate travel in New South Wales, Victoria, and the Australian Capital Territory was involved in the follow-up of family members. It was found unsatisfactory to rely on medical reports, nor was it possible to make use of other personnel, medically trained or otherwise, as in such circumstances gross misclassification was frequent and pedigree data were most inadequately recorded. The results are thus those of a personal series collected by one of us (D.C.W.). All but four of the Huntington's choreics listed as living at the commencement of the study have been seen by one of us and these four have been seen by associates working on this study, but have not been seen by us for various reasons, principally because of distance. In regard to the pedigree data, much of the material has, for lack of other means of checking, been obtained by word of mouth from surviving relatives, but in the crosscorrelation of the details given by various family members an apparently reliable history generally appears. In most cases the histories are internally consistent, and only where this is so have the data been included for analysis in this report. A summary of the data is set out in the Appendix.

\section{COMPOSITION OF SAMPLE}

Forty-seven separate kindreds were ascertained that were not definitely linked to a common ancestor. Among these a total of 108 cases of Huntington's chorea living on 1 January 1969 were examined. The family origins could be traced back only a few generations with certainty in most cases, and some of the kindreds may therefore have represented branches of a single larger pedigree. Their origins as determined, are set out in Table 1 and represent a fair approximation to the known proportionate ancestry of the Queensland population. There was only one representative of the large family detailed by Brothers (1949). Altogether some details were obtained concerning a total of 287 cases of Huntington's chorea belonging to these families.

TABLE 1

ORIGINS OF EARLIEST KNOWN CARRIER IN FAMILIES STUDIED

\begin{tabular}{llll}
\hline \multicolumn{3}{c}{ Australia } & \multicolumn{2}{c}{ Overseas } \\
\hline Queensland & 8 & England & 13 \\
New South Wales & 7 & Scotland & 6 \\
Victoria & 4 & Ireland & 5 \\
& & Sweden & 1 \\
& Germany & 1 \\
& Malta & 1 \\
& Russia & 1 \\
\hline
\end{tabular}

\section{CLINICAL EVIDENCE OF VARIATION BETWEEN KINDREDS}

Early in the investigation it became obvious that on clinical grounds it was easy to recognize that the disease ran a similar course in each family and that the symptom complex varied from one family to another. There were families in whom the disease was severe with gross chorea, familiesi in whom the disease was no more than a pre senile dementia, families in whom intellectua 5 function was well preserved until old age, ando so on. In other words, to a clinician it was. obvious that at the clinical level the concept of 'biotype' had justification. The major measurable quantities such as age at onset, age at death, and duration of symptoms were recorded for statistical analysis and bear out the clinical impression. More difficult to define in measurable terms is the symptom complex shown in each individual kindred. The clearest way to record this difference is to record aberrant patterns and to discuss their family aggregation.

Perhaps the most unusual family in this regard was the $\mathrm{K}$ family, a large kindred centred at present in Townsville, but with representatives all over Eastern Australia. A member of this family has been reported previously (Tyrer, 1957) in a discussion of the differentiation of hysteria from organic disease. Tyrer's description of this man is of interest for he showed spasmodic torticollis, involuntary clonic movements of the left lower part of the face and aphonia at the age of 22 years having commenced to show symptoms at 
the age of 20 years. He died in 1967 at the age of 32 years suffering from advanced Huntington's chorea. It was the opinion of this author that the aphonia was of a hysterical nature, but in this family there are at present living five other patients, four women and one man, two sisters, a niece and a second cousin of this case and her son in whom the first evidence of the onset of the disorder has been the onset in late teens and early 20 s of aphonia with exactly the same 'hysterical' features noted by Tyrer: inability to converse except in a whisper with phonation on coughing, but able to speak under the influence of strong emotion or, in the case of the man, to sing under the influence of alcohol. This family is also notable for the early age at onset of the disorder, the lengthy duration of the disease in some of the cases (40 years in one man) and the retention of a reasonable degree of intellect despite an appearance of gross dementia with chorea, hypertonia, mask-like facies, drooling salivation, and the aphonia described above. These features are sufficient to classify these patients as suffering from the Westphal variant of Huntington's chorea, though with rather less rigidity and dementia and rather more chorea than is usually seen in this form. All four living affected members and the case reported by Tyrer were of this type. Family descriptions suggest that other deceased members of this family may have presented a more typical picture of Huntington's disease, but the fact remains that these four cases were the only patients in the Queensland study to present with this picture, though others were seen presenting aphonia, akinesia, rigidity as late and terminal complications of the disorder.

Another family in which the disease had run a very similar course through several collateral lines was the E family. This family has previously been described by Parker (1958) and to it belonged the identical twins with the history of incendiarism and paranoid traits described by him. The disease in this family is late in onset, slow in progression, associated with little intellectual impairment but accompanied by considerable personality disturbance, the males in particular frequently showing aggressive psychopathic behaviour. The neurological features of the disease are those of typical Huntington's chorea. No patient has been diagnosed as suffer- ing from the disease in this family below 35 years of age and one old lady was examined once at 72 and considered normal and again at 74 years when she showed obvious mild evidence of the disease. No one has died from the disease below 66 years of age, but one choreic succumbed to carcinoma at the age of 41 years. This family has remained reasonably highly placed on the social scale. Its members are for the most part well-todo landholders and some are wealthy. Perhaps this is due to cultural inheritance, but, on the other hand, the late onset of the disorder does make maintenance of the integrity of the family less of a problem than in some other kindreds.

In distinction to these two families who represent opposite extremes of the condition, there is the more typical family represented by the A kindred. This pedigree is descended from a Maltese kindred, three representatives of which migrated to Australia and all three subsequently died of Huntington's chorea. There have been no unusual features among the 11 choreics from four sibships in this family. The average age at onset is 31.0 years. There is clinically very gross chorea, gross dementia, and gross emotional disturbance with the characteristic extraordinarily selfish egocentric personality of the typical Huntington's choreic. In three sibships different cultural influences have operated. One has sunk low on the social scale, its choreic members having come in contact with the police through drunkenness and violent behaviour. One sibship has been brought up in the confines of a strict and small religious sect, its affected male member having been a missionary in India, but he now has a record of violent behaviour to his wife and is institutionalized because of this. The third sibship grew up in a lower middle class environment, its affected male member having a record of petty delinquency and juvenile brushes with police and other authority. The pattern of behaviour is very similar, though the cultural background has varied widely in this kindred.

These are merely examples of recorded clinical impressions. Darwin is quoted as saying ' $I$ have no faith in anything but measurement and the rule of three'. We now proceed to attempt a demonstration of statistically significant findings that suggest that there is a basic variation of types of Huntington's chorea. 
TABLE 2

MEAN AGE AT ONSET OF HUNTINGTON'S CHOREA FOR MALES AND FEMALES OF 12 FAMILIES

\begin{tabular}{|c|c|c|c|c|c|c|c|c|c|c|c|c|}
\hline & \multicolumn{12}{|c|}{ Fainily code } \\
\hline & $K$ & $F$ & $A$ & $M$ & $G$ & $O$ & $H$ & $N$ & $D$ & $I$ & $E$ & $L$ \\
\hline $\begin{array}{l}\text { Males } \\
\text { Females }\end{array}$ & $\begin{array}{l}20 \cdot 0 \\
36 \cdot 4 \\
\end{array}$ & $\begin{array}{l}32 \cdot 3 \\
29 \cdot 0 \\
\end{array}$ & $\begin{array}{l}30 \cdot 5 \\
31 \cdot 8 \\
\end{array}$ & $\begin{array}{l}26 \cdot 5 \\
36 \cdot 0\end{array}$ & $\begin{array}{l}44 \cdot 0 \\
30 \cdot 3 \\
\end{array}$ & $\begin{array}{l}31 \cdot 7 \\
38 \cdot 0 \\
\end{array}$ & $\begin{array}{l}35 \cdot 8 \\
54 \cdot 0 \\
\end{array}$ & $\begin{array}{l}47 \cdot 0 \\
40 \cdot 0\end{array}$ & $\begin{array}{l}44 \cdot 0 \\
45 \cdot 0\end{array}$ & $\begin{array}{l}46 \cdot 8 \\
48 \cdot 0\end{array}$ & $\begin{array}{l}45 \cdot 6 \\
54 \cdot 8\end{array}$ & $\begin{array}{l}52.0 \\
55.0\end{array}$ \\
\hline Total & $30 \cdot 5$ & $30 \cdot 6$ & $31 \cdot 0$ & $33 \cdot 3$ & $35 \cdot 8$ & $35 \cdot 9$ & $39 \cdot 4$ & $43 \cdot 5$ & $44 \cdot 6$ & $47 \cdot 3$ & 49.9 & $53 \cdot 5$ \\
\hline $\begin{array}{l}\mathrm{n}_{\mathrm{M}} \\
\mathrm{n}_{\mathrm{F}}\end{array}$ & $\begin{array}{l}4 \\
7\end{array}$ & $\begin{array}{l}4 \\
4\end{array}$ & $\begin{array}{l}6 \\
4\end{array}$ & $\begin{array}{l}2 \\
5\end{array}$ & $\begin{array}{l}2 \\
3\end{array}$ & $\begin{array}{l}3 \\
6\end{array}$ & $\begin{array}{l}8 \\
2\end{array}$ & $\begin{array}{l}2 \\
2\end{array}$ & $\begin{array}{l}5 \\
3\end{array}$ & $\begin{array}{l}4 \\
3\end{array}$ & $\begin{array}{l}7 \\
6\end{array}$ & $\begin{array}{l}2 \\
2\end{array}$ \\
\hline $\mathrm{n}_{\text {Tot }}$ & 11 & 8 & 10 & 7 & 5 & 9 & 10 & 4 & 8 & 7 & 13 & 4 \\
\hline
\end{tabular}

\section{ANALYSIS OF DATA}

Table 2 shows mean age at onset, for males and females separately, over 12 families (not less than two cases per sex per family). A two-way analysis of variance (sex and families) was then carried out, treating families ${ }^{2}$ as a random effect. The results are summarized in Table $3 \mathrm{a}$. A similar analysis on duration of the disease produced no significant results (see Table $3 b$ ).

\section{TABLE 3a}

ANALYSIS OF VARIANCE* OF AGES AT ONSET OF HUNTINGTON'S CHOREA FOR MALES AND FEMALES (SEX) IN 15 FAMILIES (FAM.)

\begin{tabular}{lrrrr}
\hline Source & \multicolumn{1}{c}{$S S$} & $d . f$. & \multicolumn{1}{c}{$M S$} & $F$ \\
\hline Fam. & $5556 \cdot 13$ & 11 & $505 \cdot 10$ & $6 \cdot 550 \dagger$ \\
Sex & $207 \cdot 36$ & 1 & $207 \cdot 36$ & $2 \cdot 689 \S$ \\
Fam. $\times$ sex & $1810 \cdot 96$ & 11 & $164 \cdot 63$ & $2 \cdot 135 \ddagger$ \\
Error & $5552 \cdot 54$ & 72 & $77 \cdot 12$ & \\
\hline Total & 13126.99 & 95 & & \\
\hline
\end{tabular}

* Because of fairly large inequalities between within-groups n's, Bartlett's test was applied, yielding a $x^{2}=18.24$ for 19 d.f. with associated $P \doteqdot 0 \cdot 5$, and the hypothesis of homogeneity of within-groups variance was not rejected.

† Significant at $0 \cdot 001$. $¥$ Significant at 0.05 . § NS.

In the light of the significant 'families' $\mathrm{F}$ in Table $3 \mathrm{a}$ a further analysis was carried out. If families are separated into two blocks, those with means above the grand mean ( 38.99 years) and those with means below, there appears to be: (1) some variation between family means within each block (see Table 2); and (2) except for families $\mathrm{H}$ and $\mathrm{K}$, no marked overlap between

2 If families are treated as a fixed effect, the $F$ for sex is still not significant at $\alpha=0.05$.
TABLE 3b

ANALYSIS OF VARIANCE OF DURATION OF HUNTINGTON'S CHOREA

\begin{tabular}{lrrrr}
\hline Source & \multicolumn{1}{l}{ SS } & d.f. & \multicolumn{1}{c}{$M S$} & $F^{*}$ \\
\hline 1. Fam. groups & 87.80 & 1 & 87.80 & 1.308 \\
2. Sex & $1 \cdot 19$ & 1 & 1.19 & $<1$ \\
3. Sex (fam. groups) & 37.96 & 1 & 37.96 & $<1$ \\
4. Error & 3693.17 & 55 & 67.15 & \\
\hline 5. Total & 3820.31 & 58 & & \\
\hline
\end{tabular}

* No significant F.

blocks (see Figure). It was therefore decided to partition the sums of squares between families into two components, a sum of squares betweeng family blocks as defined above and a sum of squares between families within the blocks, too test the hypothesis that differences between family means could be mainly accounted for by block differences with insignificant inter-family differences within blocks. The re-analysis thus has fixed factors, sex ${ }^{3}$ and family group and a random effect, family, nested under family group. The paradigm for such an analysis can be found in Winer (1962) and the results are set out in Table $4 \mathrm{a}$. Tests of the components involving the random factor (components (4) and (5)) at the $0 \cdot 1$ level (Winer, 1962) yielded non-significant Fs in both cases. Components (4), (5), and (6) were then pooled to obtain a revised estimate of error (Table 4b). It is arguable that the second analysis leads to a more parsimonious interpretation of the data than does the first but validation of the arbitrary classification into 'early-onset' $\left(A_{1}\right)$ and 'late-onset' $\left(A_{2}\right)$ blocks, by reference to additional data, seemed necessary. Such data,

${ }^{3}$ Retained because of the significant $\operatorname{sex} \times$ family interaction (Table 3a). 


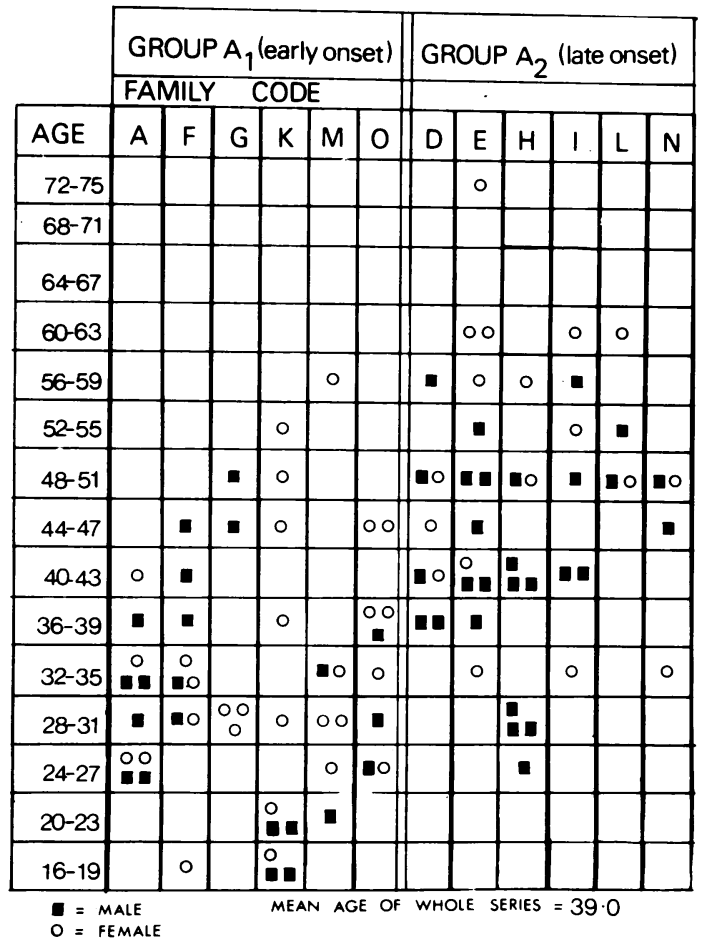

FIGURE. Age grouping of early onset and late onset cases. $\square=$ maie, $\bigcirc=$ female.

Mean age of whole series $=39 \cdot 0$ years.

in the form of families which did not meet the criterion of at least two members of each sex were available. Table 5a shows ages by family and sex, family means and family classification as $A_{1}$ or $A_{2}$-that is, above or below the grand mean ( 38.99 years) of the original data. Table $5 \mathrm{~b}$ shows the number of individuals who are "cor-
TABLE $4 \mathrm{a}$

REANALYSIS OF AGE-AT-ONSET DATA (STAGE 1)

\begin{tabular}{|c|c|c|c|c|c|}
\hline Source & & $S S$ & d.f. & $M S$ & $F$ \\
\hline 1. Fam. groups & & $4392 \cdot 32$ & 1 & $4392 \cdot 32$ & \\
\hline $\begin{array}{l}\text { 2. Fam. w. groups } \\
1 .+2 \text {. }\end{array}$ & $5556 \cdot 13$ & $1163 \cdot 81$ & 10 & $116 \cdot 38$ & $1 \cdot 51^{*}$ \\
\hline 3. Sex & & $207 \cdot 36$ & 1 & $207 \cdot 36$ & \\
\hline 4. Sex $\times$ (fam. groups) & & $584 \cdot 26$ & 1 & $584 \cdot 26$ & \\
\hline 5. Sex $\times($ fam. w. groups $)$ & & $1226 \cdot 70$ & 10 & $122 \cdot 67$ & $1 \cdot 59$ \\
\hline 4. +5 & $1810 \cdot 96$ & & & & \\
\hline 6. Error & & $5552 \cdot 54$ & 72 & $77 \cdot 12$ & \\
\hline 7. Total & & 13126.99 & 95 & & \\
\hline
\end{tabular}

*NS at $\alpha=0 \cdot 1$.

TABLE $4 \mathrm{~b}$

REANALYSIS OF AGE-AT-ONSET DATA (STAGE 2)

\begin{tabular}{lrrrr}
\hline Source & \multicolumn{1}{c}{$S S$} & d.f. & \multicolumn{1}{c}{$M S$} & \multicolumn{1}{c}{$F$} \\
\hline 1. Fam. groups & $4392 \cdot 32$ & 1 & $4392 \cdot 32$ & $50 \cdot 87^{*}$ \\
2. Sex & $207 \cdot 36$ & 1 & $207 \cdot 36$ & $2 \cdot 40 \ddagger$ \\
3. Sex $\times$ (fam. groups) & 584.26 & 1 & $584 \cdot 26$ & $6.77 \dagger$ \\
4. Error (pooled) & 7943.05 & 92 & 86.34 & \\
\hline 5. Total & 13126.99 & 95 & & \\
& & & & \\
\end{tabular}

* Significant at 0.001 .

+ Significant at 0.05 .

$\ddagger$ NS.

rectly' and 'incorrectly' classified-that is, where ages were or were not within the agerange of the block to which their family mean was allocated.

Finally an analysis of variance, in the paradigm of the analysis summarized in Table $4 \mathrm{~b}$, was carried out on ages at death and the results are summarized in Table 6.

TABLE 5a

AGE AT ONSET-ADDITIONAL DATA

\begin{tabular}{|c|c|c|c|c|c|c|c|c|c|c|c|c|}
\hline & \multicolumn{12}{|c|}{ Fainily code } \\
\hline & $B$ & $C$ & $P$ & $Q$ & $R$ & $S$ & $T$ & $U$ & $V$ & $w$ & $x$ & $Y$ \\
\hline Males & $\begin{array}{l}26,35 \\
35,35 \\
40,50\end{array}$ & $\begin{array}{l}27 \\
38\end{array}$ & $\begin{array}{l}31 \\
33\end{array}$ & 41 & & 45 & $\begin{array}{l}39 \\
50\end{array}$ & $\begin{array}{l}32 \\
60\end{array}$ & & & $\begin{array}{l}31 \\
42\end{array}$ & \\
\hline Females & 32 & 27 & & 45 & $\begin{array}{c}44.49 \\
62\end{array}$ & 40 & & & $\begin{array}{l}32 \\
40\end{array}$ & $\begin{array}{l}13 \\
29 \\
\end{array}$ & & $\begin{array}{l}49 \\
52\end{array}$ \\
\hline $\begin{array}{l}\text { Family mean } \\
\text { Onset group }\end{array}$ & $\begin{array}{r}36 \cdot 1 \\
A_{1}\end{array}$ & $\begin{array}{r}30 \cdot 7 \\
\mathbf{A}_{1}\end{array}$ & $\begin{array}{r}32 \cdot 0 \\
A_{1}\end{array}$ & $\begin{array}{r}43 \cdot 0 \\
A_{2}\end{array}$ & $\begin{array}{r}51 \cdot 7 \\
A_{2}\end{array}$ & $\begin{array}{r}42 \cdot 5 \\
A_{2}\end{array}$ & $\begin{array}{r}44 \cdot 5 \\
\mathrm{~A}_{2}\end{array}$ & $\begin{array}{r}46 \cdot 0 \\
\mathrm{~A}_{2}\end{array}$ & $\begin{array}{r}36 \cdot 0 \\
A_{1}\end{array}$ & $\begin{array}{r}21 \cdot 0 \\
A_{1}\end{array}$ & $\begin{array}{r}36 \cdot 5 \\
A_{1}\end{array}$ & $\begin{array}{r}50 \cdot 5 \\
\mathrm{~A}_{2}\end{array}$ \\
\hline
\end{tabular}


TABLE 5b

AGE AT ONSET-ADDITIONAL DATA (SEXES COMBINED)

\begin{tabular}{llllllllllllllll}
\hline & \multicolumn{1}{c}{} & \multicolumn{1}{c}{ Family code } & \multicolumn{1}{c}{ Total $\uparrow$} \\
\cline { 2 - 7 } & $B$ & $C$ & $P$ & $Q$ & $R$ & $S$ & $T$ & $U$ & $V$ & $W$ & $X$ & $Y$ & \\
\hline No. correct & 5 & 3 & 2 & 2 & 3 & 2 & 2 & 1 & 1 & 2 & 1 & 2 & 26 \\
No. incorrect & 2 & 0 & 0 & 0 & 0 & 0 & 0 & 1 & 1 & 0 & 1 & 0 & 5 \\
\hline
\end{tabular}

* 'Correct' and 'incorrect' classifications-that is, individuals within and without family classification range.

$\dagger x^{2}$ on totals (corrected for continuity) $=12.9$ for 1 d.f.; $\mathrm{P}<0.001$.

TABLE 6

ANALYSIS OF VARIANCE OF AGES AT DEATH OF HUNTINGTON'S CHOREA CASES

\begin{tabular}{lrrrc}
\hline Source & \multicolumn{1}{c}{$S S$} & d.f. & \multicolumn{1}{c}{$M S$} & \multicolumn{1}{c}{$F$} \\
\hline 1. Fam. groups & 1873.84 & 1 & 1873.34 & $16.63^{*}$ \\
2. Sex & 681.04 & 1 & $\mathbf{6 8 1 . 0 4}$ & $6.05 \dagger$ \\
3. Sex $\times$ (fam. groups) & 80.82 & 1 & 80.82 & $<1$ \\
4. Error & 8450.50 & 75 & 112.67 & \\
\hline 5. Total & 11085.56 & 78 & & \\
\hline
\end{tabular}

* Significant at 0.001 .

$\dagger$ Significant at 0.05 .

DISCUSSION OF ANALYSES It seems to have been demonstrated, beyond reasonable doubt, that inter-family differences in the onset age of Huntington's chorea significantly exceed intra-family differences, and sex differences are not uniform across families. More parsimoniously, it seems possible that a hypothesis of at least two major genetically-differentiated groupings is tenable. This hypothesis receives some support from an analysis of data which are independent of the data generating the hypothesis.

No evidence was found of significant differences in duration of the disease. The pattern of ages at death is, in general, consistent with the foregoing findings. The inter-group significant difference is maintained. The change in the sex difference from non-significant at onset to significant at death is probably a reflection of the greater mean female longevity in the general population and the change in the $\operatorname{sex} \times$ family interaction (significant at onset; non-significant at death) could be due to the increase in magnitude of the sex main-effect at death. The whole pattern seems to exhibit some coherence. It might be argued that the similarities noted above are due to the effects of a common environment within sibships, and not a reflection of an underlying genetic difference. For this reason, a comparison of the correlations between sib-sib pairs, parent-child pairs, and cousin-cousin pairs was made. The results are set out in Table 7 . It can be seen that, where comparison is possible, the correlations are all strongly positive except in the case of duration in parent-child pairs. In this instance the observational errors associated with the spurious entity known as anticipation (Penrose, 1948) are conceivably responsible. Though not suitable for strict significance testing, these

\section{TABLE 7}

INTRACLASS* CORRELATIONS $\dagger$ WITHIN THREE RELATIONSHIP GROUPS OVER ONSET-AGE, DEATH-AGE, AND DURATION

\begin{tabular}{|c|c|c|c|}
\hline & Sib-sib & Parent-child & Cousin-cousin \\
\hline Onset & $\begin{array}{c}+53 \\
(100 \text { pairs })\end{array}$ & $\begin{array}{c}+44 \\
(60 \text { pairs })\end{array}$ & $\begin{array}{c}+44 \\
\text { (97 pairs) }\end{array}$ \\
\hline Death & $\begin{array}{c}+51 \\
\text { (51 pairs) }\end{array}$ & $\begin{array}{c}+59 \\
\text { (41 pairs) }\end{array}$ & 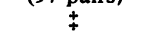 \\
\hline Duration & $\begin{array}{c}+77 \\
\text { (30 pairs) }\end{array}$ & $\begin{array}{c}-27 \\
\text { (20 pairs) }\end{array}$ & $\ddagger$ \\
\hline
\end{tabular}

* Since families with different $n$ 's are aggregated, these are not intra class correlations in the strict sense (Fisher, 1946). No significance test can therefore be made.

$\uparrow$ Decimal points omitted.

$\ddagger$ Insufficient data.

findings strongly suggest that the similarities are due to genetic variation and not environmental similarities. Moreover, the lack of falling off in the cousin-cousin pair correlation suggests that it is the major gene which varies from family to family, and not the effect of a common genetic background influencing the action of the Huntington's allele.

\section{DISCUSSION}

It can be accepted on the basis of the findings presented here that the pattern of disease seen in Huntington's chorea runs in families, so that the differences between individuals within pedigrees are less than the differences between pedigrees. This finding is not new. Reed and Chandler (1959) with their somewhat larger data 
analysed the differences in age of onset, at death, and in duration between sibships between kindreds and within kindreds and found that the similarity was greatest within a sibship, rather less between members of one kindred, and least between unrelated cases. They interpreted this as evidence in favour of a single Huntington's chorea gene acting against a background of common genes in the same family. Familial similarities in expression of Huntington's chorea have been examined by other workers. Fieller and Smith (1951) found positive correlations between siblings for ages at onset and death. Bell (1948) using material from published data found a high sib-sib correlation, and as long ago as 1899 Beeton and Pearson found a significant correlation of 0.26 between brothers in age at death.

The difficulty is to decide whether this is due to variations in the different Huntington's chorea alleles, or due to similarities in the genetic background within families. We interpret our evidence as supporting the hypothesis of variable alleles, though it is probable that a common genetic background and a common environment within sibships play a part. Indeed, the data from Reed and Chandler's study show that siblings suffering from the condition resemble one another more than do relatives within a kindred, though the differences are not significant. Though we know of no environmental influence which has any bearing on the time of onset or the rate of progression of Huntington's chorea, it would $a$ priori be expected that such influences do exist, and the same is true for the influence of the total genotype. However, the clinical similarities between the symptom complex of the disorder in widely separated segments of a single kindred, and the quite startling differences between the expression of the disease in different families, makes the clinician incline to the opinion that different Huntington's chorea alleles are effecting this difference. This opinion receives support from the statistical analysis presented, which shows, not only that there is a significantly greater difference in at least one variable-namely, age at onset-between families than within families, but suggests that there are at least two separate forms of the disorder distinguished by relatively early and relatively late onset.

In the present state of knowledge concerning
Huntington's chorea, where there is no understanding of the biochemical abnormality underlying the condition it is perhaps unwise to speculate in regard to its nature, but the genetic knowledge concerning the disorder allows certain tentative conclusions to be drawn. The mode of inheritance is that of a classical mendelian dominant. Although a minor structural rearrangement of chromosomal material such as a small deletion, duplication, or translocation could be responsible, it is more probable that the disease represents a point mutation in a structural or control gene. If this is so then it might be expected to behave in a similar manner to similar point mutations, with a recurrence rate of approximately one per $10^{5}$ gametes, and as each structural locus or control locus represents a DNA segment of perhaps $10^{3}$ base pairs, change in any pair of which might cause a disease of Huntington's type to appear, it is to be expected that these varying mutations would differ in their phenotypic effects one from another while breeding true in the same family. Less likely, in view of the conspicuous isolation of Huntington's chorea from all other genetically determined degenerative disorders of the nervous system, is the possibility that mutant alleles at different loci are responsible for the variant diseases in different families, in a manner analogous to the two loci responsible for ovalocytosis (Morton, 1956).

Myrianthopoulos (1966) recognized three separate clinical forms of the disease: the general case of Huntington's chorea, the rigid and akinetic form, and the childhood form of the disease. These correspond to Bruyn's adult type, Westphal variant, and juvenile types. We have not recorded a case of the childhood type. There have been several children of choreics who suffered from epilepsy, but on each occasion when the child was examined no evidence to suggest Huntington's chorea was detected. These juvenile cases have been reported to occur sporadically among families with the typical adult form of the disease. Without personal experience of such cases we cannot comment upon their significance, except to suggest that the complete absence of any records of such cases among nearly 300 well-documented cases from the Queensland kindreds either suggests that this form is very rare or that among the 47 Queens- 
land kindreds there is no representative of the particular Huntington's chorea allele that is capable of giving rise to this syndrome. As recorded, we have encountered five living examples of the Westphal variant of the disorder and obtained the records of a sixth and seventh. We consider it suggestive that all seven of these are representatives of a single kindred that is aberrant in other ways. We consider that this particular form of Huntington's chorea is, on the evidence available, more probably the result of a separate mutant allele than the result of a predisposing background of common genes within this family.

\section{REFERENCES}

Beeton, M., and Pearson, K. (1899). Data for the problem of evolution in man. II. A first study of the inheritance of longevity and the selective death-rate in man. Proceedings of the Royal Society, 65, 290-305.

Bell, J. (1948). Huntington's chorea, pp. 1-67. In Nervous Diseases and Muscular Dystrophies. The Treasury of Human Inheritance. Vol. IV. Cambridge University Press: London.

Bittenbender, J. B., and Quadfasel, F. A. (1962). Rigid and akinetic forms of Huntington's chorea. Archives of Neurology (Chicago), 7, 275-288.

Brothers, C. R. D. (1949). The history and incidence of Huntington's chorea in Tasmania. Proceedings of the Royal Australasian College of Physicians, 4, 48-50.

Bruyn, G. W. (1968). Huntington's chorea. Historical, clinical and laboratory synopsis, pp. 298-378. In Handbook of
Clinical Neurology. Vol. 6. Diseases of the Basal Ganglia. Edited by P. J. Vincken and G. W. Bruyn. North-Holland: Amsterdam.

Chandler, J. H., Reed, T. E., and DeJong, R. N. (1960). Huntington's chorea in Michigan. III. Clinical observations. Neurology (Minneap.), 10, 148-153.

Davenport, C. B., and Muncey, E. B. (1916). Huntington's chorea in relation to heredity and eugenics. American Journal of Insanity, 73, 195-222.

Fieller, E. C., and Smith, C. A. B. (1951). Note on the analysis of variance and intraclass correlation. Annals of Eugenics, 16, 97-104.

Fisher, R. A. (1946). Statistical Methods for Research Workers. 10th edn. Oliver and Boyd: Edinburgh.

McKusick, V. A. (1971). Mendelian Inheritance in Man. 3rd edn. Johns Hopkins Press: Baltimore.

Morton, N. E. (1956). The detection and estimation of linkage between the genes for elliptocytosis and the $\mathrm{Rh}$ blood type. American Journal of Human Genetics, 8, 80-96.

Müller-Küppers, M., and Stenzel, K. (1963). Zum Problem der Frühmanifestation der Erbchorea. Acta Paedopsychiatrica, 30, 348-355.

Myrianthopoulos, N. C. (1966). Huntington's chorea. Journal of Medical Genetics, 3, 298-314.

Parker, N. (1958). Observations on Huntington's chorea based on a Queensland survey. Medical Journal of Australia, 1, 351-359.

Penrose, L. S. (1948). The problem of anticipation in pedigrees of dystrophia myotonica. Annals of Eugenics, 14, 125-132.

Reed, T. E., and Chandler, J. H. (1958). Huntington's chorea in Michigan. I. Demography and genetics. American Jour= nal of Human Genetics, 10, 201-225.

Tyrer, J. H. (1957). The differentiation of hysteria from organic neurological disease. Medical Journal of Australia 1, 566-571.

Winer, B. J. (1962). Statistical Principles in Experimenta? Design. McGraw-Hill: New York.
In drawing up this appendix an effort has been made to codify as much information as possible in the smallest possible amount of space. The result may be a little confusing but the numbers specify the following rough estimates. Movement: $0=$ no abnormal movement, $1=$ minimal chorea, $2=$ moderate chorea, $3=$ marked chorea. Dementia, marital disturbance, anger outbursts, alcoholism, and sexual aberration are coded along similar lines. Psychiatric disturbance uses a finer grading from 0 , which indicates no detectable disturbance, to 9 , which indicates a state equivalent to raving lunacy. In 'Age at death' column, L denotes 'living'. Inst. in the column 'Ever in mental hospital' refers to placement in nursing home or similar custodial accommodation. The appendix contains all data from which the statistical analysis was made. It does not include the many ancestral cases for whom no accurate data were available. The pedigree number is that of the catalogue of genetic defects at Queensland Institute of Medical Research, which includes disorders other than Huntington's chorea. 


\begin{tabular}{|c|c|c|c|c|c|c|c|c|c|c|c|c|c|c|c|c|}
\hline 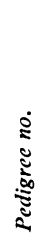 & & 气̆ & ڤั̆ & 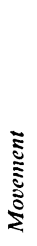 & 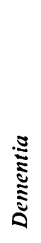 & 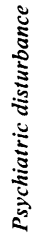 & 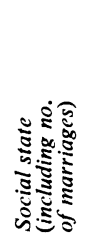 & 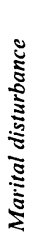 & 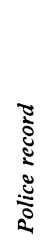 & 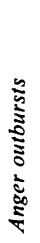 & 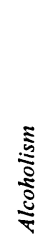 & 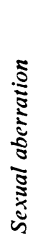 & 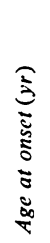 & 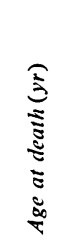 & 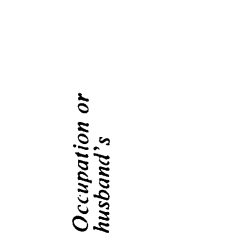 & 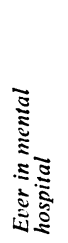 \\
\hline 12 & & $\left.\mathrm{II}_{2}\right\} \mathrm{Sib}$ & $\mathbf{M}$ & & & & & & & & & & 38 & 54 & & \\
\hline 12 & & $\left.\mathrm{II}_{4}\right\} \mathrm{Sib}$ & $\mathbf{M}$ & 3 & 3 & 9 & 1 & 1 & 0 & 3 & - & - & & 43 & Labourer & Inst. \\
\hline 12 & & (III & $\mathbf{M}$ & 2 & 3 & 9 & 0 & - & + & 3 & $=$ & 二 & 25 & L & Labourer & $\begin{array}{l}\text { Yes } \\
\text { Yes }\end{array}$ \\
\hline 12 & & $\mathrm{III}_{3}$ & $\mathbf{F}$ & 2 & 3 & - & 0 & - & 0 & - & $\overline{0}$ & 二 & 35 & L & Nil & $\begin{array}{l}\text { Yes } \\
\text { Yes }\end{array}$ \\
\hline 12 & & $\mathrm{IIII}_{\mathrm{B}}$ & M & 3 & 3 & - & 1 & 二 & - & 3 & 3 & 二 & 25 & 36 & Meat worker & \\
\hline 12 & Sib & $\mathrm{III}_{7}$ & M & 3 & 3 & 9 & 0 & 二 & + & 3 & 3 & $\overline{3}$ & 33 & $\mathrm{~L}$ & Labourer & Yes \\
\hline 12 & & $\mathrm{III}_{8}$ & $\mathbf{M}$ & 3 & 1 & 7 & 0 & - & - & 3 & 3 & - & 30 & $L$ & Meat worker & No \\
\hline 12 & & IIII & $\mathrm{F}$ & - & & - & 1 & 1 & + & 3 & - & - & 27 & L & Wharfie & No \\
\hline 12 & & $\mathrm{IIII}_{13}$ & $F$ & 3 & 3 & 6 & 1 & 0 & $\overline{0}$ & 1 & 0 & 0 & 25 & L & Reg. army & Inst. \\
\hline 12 & $\mathrm{Sib}$ & $\left\{\mathrm{III}_{17}\right.$ & $\mathrm{F}$ & 0 & 3 & $\overline{0}$ & 1 & 0 & 0 & 0 & 0 & 0 & 40 & $\mathbf{L}$ & Shopkeeper & Yes \\
\hline 12 & & $\left\{\begin{array}{l}\mathrm{III}_{23} \\
\mathrm{II}_{2}\end{array}\right.$ & $\mathbf{M}$ & 1 & 1 & 9 & 1 & 2 & 0 & 3 & 0 & 0 & 32 & L & Missionary & Yes \\
\hline 13 & & $\mathrm{II}_{3}$ & $\mathbf{M}$ & 3 & 3 & 3 & 1 & 0 & 0 & - & 3 & 0 & 40 & 53 & Estate agent & Yes \\
\hline 13 & Sib & $\mathrm{II}_{7}$ & $\mathbf{M}$ & 3 & 3 & 3 & 1 & 0 & $\mathbf{0}$ & - & - & - & 40 & 52 & Baker & No \\
\hline 13 & & $\mathrm{III}_{9}$ & $\mathrm{~F}$ & 3 & 3 & 3 & 1 & 1 & 0 & 1 & 0 & 0 & 32 & 42 & Storekeeper & Yes \\
\hline 13 & & $\mathrm{III}_{4}$ & $\mathbf{M}$ & 2 & 0 & 0 & & 0 & 0 & 0 & 0 & 0 & 50 & L & Telephone worker & No \\
\hline 13 & Sib & $\mathrm{III}_{6}$ & $\mathbf{M}$ & 3 & 3 & 6 & 0 & 0 & 0 & 3 & 3 & 0 & 35 & 47 & Real estate agent & Yes \\
\hline 13 & Sib & $\mathrm{III}_{7}$ & $\mathbf{M}$ & 3 & 3 & 9 & 1 & 1 & 0 & 3 & 0 & - & 26 & 43 & Dairy inspector & Yes \\
\hline 13 & & $\mathrm{IIII}_{9}$ & $F$ & 2 & 1 & 0 & 1 & $\mathbf{0}$ & $\mathbf{0}$ & - & 0 & 0 & 32 & L & Bank clerk & No \\
\hline 13 & & $\mathrm{III}_{20}$ & $\mathbf{M}$ & 1 & 0 & 6 & 0 & 0 & + & - & 3 & - & 35 & $\mathbf{L}$ & A.L.P. secretary & No \\
\hline 13 & & $\mathrm{III}_{23}$ & M & 1 & 0 & 0 & 1 & 0 & 0 & - & - & - & 35 & L & Shearer & No \\
\hline 14 & & $\mathrm{II}_{1}$ & M & 3 & 3 & 9 & 1 & - & - & 3 & - & - & 32 & 45 & & Yes \\
\hline 14 & & $\mathrm{III}_{1}$ & M & 3 & 3 & 9 & 1 & 1 & - & 3 & 0 & 0 & - & 58 & Chemist & Yes \\
\hline 15 & & $\mathrm{III}_{2}$ & M & 3 & 3 & 9 & 1 & 3 & + & 3 & 0 & 1 & 42 & $\mathbf{L}$ & Miner & Yes \\
\hline 16 & $\mathrm{Sib}$ & $\left\{\mathrm{IV}_{1}\right.$ & M & 3 & 3 & & 1 & 3 & 0 & 3 & 3 & - & 38 & 53 & Newspaper reporter & Yes \\
\hline 16 & & $\begin{array}{l}\mathrm{IIV}_{5} \\
\mathrm{IV}_{4}\end{array}$ & $\stackrel{M}{M}$ & $\begin{array}{l}3 \\
3\end{array}$ & $\begin{array}{l}3 \\
3\end{array}$ & $\begin{array}{l}9 \\
9\end{array}$ & 1 & 3 & 0 & 3 & 3 & $\overline{-}$ & 27 & 50 & Lieutenant & Yes \\
\hline 16 & & $I_{9}$ & $\mathrm{~F}$ & 3 & 3 & 9 & 1 & 0 & 0 & 1 & $\overline{0}$ & $\overline{2}$ & 27 & $\stackrel{?}{\mathrm{~L}}$ & Artisan & $\begin{array}{l}\text { Yes } \\
\text { Yes }\end{array}$ \\
\hline 19 & & $\mathrm{II}_{2}$ & M & - & - & _ & - & - & - & $\underline{-}$ & - & $\underline{-}$ & 48 & L & & $\begin{array}{l}\text { Yes } \\
\text { Yes }\end{array}$ \\
\hline 19 & & $\mathrm{CIII}_{4}$ & $\mathrm{~F}$ & & 3 & 9 & $\overline{1}$ & $\overline{1}$ & - & $\overrightarrow{3}$ & $\overline{0}$ & $\overline{0}$ & $\begin{array}{l}40 \\
50\end{array}$ & $\overline{58}$ & Labourer - & $\begin{array}{l}\text { Yes } \\
\text { Yes }\end{array}$ \\
\hline 19 & & $\mathrm{III}_{10}$ & $\mathrm{~F}$ & 3 & 2 & 3 & 1 & 0 & $\overline{0}$ & 3 & 0 & 0 & 40 & $\begin{array}{l}38 \\
54\end{array}$ & $\begin{array}{l}\text { Labourer } \\
\text { Labourer }\end{array}$ & Yes \\
\hline 19 & $\mathrm{Sib}$ & $\mathrm{III}_{12}$ & $\mathrm{~F}$ & 3 & 2 & 3 & 1 & 3 & + & 3 & 3 & 3 & & $\begin{array}{l}34 \\
48\end{array}$ & $\begin{array}{l}\text { Labourer } \\
\text { SP bookie }\end{array}$ & No \\
\hline 19 & & $\mathrm{III}_{14}$ & M & 1 & 0 & 0 & 1 & 0 & 0 & 0 & 0 & 0 & 57 & $\begin{array}{l}48 \\
L\end{array}$ & Meat worker & No \\
\hline 19 & & $\mathrm{IIII}_{18}$ & M & 2 & 3 & 6 & 1 & 0 & 0 & 0 & 0 & 0 & 40 & 53 & & \\
\hline 19 & & $\mathrm{IV}_{2}$ & $\mathrm{~F}$ & 2 & 1 & 3 & 2 & 3 & - & - & 0 & 1 & 45 & $\mathrm{~L}$ & & \\
\hline 19 & $\mathrm{Sib}$ & $\left\{\mathrm{IV}_{45}^{2}\right.$ & M & 0 & 0 & 6 & 1 & 3 & - & 3 & 3 & 0 & 39 & $\mathrm{~L}$ & Wharfie & No \\
\hline 19 & & $\left\{I_{47}\right.$ & M & 1 & 0 & 0 & 1 & 2 & - & 3 & 3 & 0 & 38 & $\mathrm{~L}$ & Process worker & No \\
\hline 22 & & $\mathrm{III}_{2}$ & $\mathrm{~F}$ & 3 & 1 & 0 & 1 & 0 & 0 & 0 & 0 & 0 & 55 & 73 & Officer, fire brigade & No \\
\hline 22 & & $\mathrm{III}_{15}$ & $\mathbf{M}$ & 3 & 3 & 9 & 1 & 3 & 0 & 3 & 0 & 0 & 60 & $>72$ & Sailmaker & No \\
\hline 23 & & $\mathrm{III}_{4}$ & $\mathrm{~F}$ & 3 & 0 & 3 & 1 & 1 & & 3 & & 0 & 57 & 66 & & $\begin{array}{l}\text { Inst. } \\
\text { No }\end{array}$ \\
\hline 23 & & $\mathrm{IV}_{1}$ & $\mathrm{~F}$ & 3 & 0 & 3 & 1 & 1 & 0 & 2 & 0 & 0 & 62 & 85 & Farmer & $\begin{array}{l}\text { No } \\
\text { No }\end{array}$ \\
\hline 23 & & $\mathrm{IV}_{6}$ & $\mathbf{M}$ & 3 & 3 & 9 & 1 & 3 & + & 0 & 0 & 0 & 42 & 66 & Successful timber & \\
\hline 23 & $\mathrm{Sib}$ & $\mathrm{IV}_{8}$ & $\mathbf{M}$ & 3 & 3 & 9 & 1 & 2 & 0 & 3 & 0 & 0 & 42 & 66 & $\begin{array}{l}\text { merchant } \\
\text { Share farmer }\end{array}$ & $\begin{array}{l}\text { Yes } \\
\text { Yes }\end{array}$ \\
\hline 23 & & $\mathrm{IV}_{13}^{\circ}$ & $\mathrm{F}$ & 3 & 3 & 9 & 1 & 1 & + & 3 & 0 & 0 & 61 & 76 & & Yes \\
\hline 23 & & $I V_{15}$ & $F$ & 1 & 0 & 0 & 1 & 0 & 0 & $\mathbf{0}$ & 0 & 0 & 74 & $\mathbf{L}$ & Farmer & No \\
\hline 23 & & $\mathrm{~V}_{1}$ & M & 1 & 1 & 0 & 1 & 0 & 0 & 0 & 0 & 0 & 53 & L & Telephone lineman & No \\
\hline 23 & Sib & $\mathbf{v}_{3}$ & M & 3 & 1 & $\mathbf{0}$ & 1 & 0 & 0 & $\mathbf{0}$ & 0 & 0 & 51 & L & & No \\
\hline 23 & & $V_{5}$ & M & 3 & 2 & 0 & 1 & 0 & 0 & 0 & 0 & 0 & 50 & L & Farmer & No \\
\hline 23 & & $V_{34}$ & $\mathrm{M}$ & 2 & 2 & 6 & 1 & 3 & 0 & 3 & 3 & 0 & 45 & $\mathbf{L}$ & Farmer & Yes \\
\hline 23 & Sib & $V_{36}$ & $\mathrm{~F}$ & 2 & 0 & 0 & 1 & 3 & 0 & 0 & 0 & 0 & 40 & 41 & Trained nurse & No \\
\hline 23 & & $V_{38}$ & $\mathrm{M}$ & 1 & 0 & 1 & 1 & 0 & 0 & 1 & 0 & 0 & 36 & $\mathbf{L}$ & Railwayman & No \\
\hline 23 & & $V_{46}$ & $F$ & 3 & 2 & 3 & 1 & 0 & 0 & 2 & 1 & 0 & 35 & $\mathbf{L}$ & Farmer & Yes \\
\hline 24 & & $\mathrm{III}_{5}$ & $\mathbf{M}$ & 2 & 1 & 0 & 1 & 3 & 0 & 3 & 0 & 0 & 45 & L & Company manager & No \\
\hline 26 & & $\mathrm{III}_{2}$ & $\mathrm{~F}$ & 3 & - & _ & 1 & 0 & 0 & - & - & - & - & 56 & $\begin{array}{l}\text { Grazier } \\
\text { Grazier }\end{array}$ & No \\
\hline $\begin{array}{l}26 \\
26\end{array}$ & & $\left\{\begin{array}{l}\mathrm{II}_{10} \\
\mathrm{II}_{10}\end{array}\right.$ & $\mathbf{M}$ & & & & 1 & & & & & & & $\begin{array}{l}54 \\
63\end{array}$ & & No \\
\hline & Sib & & & & & & & & & & & & & & & Inst. \\
\hline $\begin{array}{l}26 \\
26\end{array}$ & & $\begin{array}{l}I_{11} \\
I_{11}\end{array}$ & F & & & & 1 & & & & & & & $\begin{array}{l}63 \\
72\end{array}$ & & No \\
\hline 26 & & $\mathrm{CIII}_{3}$ & $\mathbf{F}$ & 3 & 3 & 6 & 1 & 3 & 0 & 2 & & & 35 & 42 & Garage propri & Yes \\
\hline 26 & Sib & $\mathrm{IIII}$ & $F$ & & & & 1 & & & & & & 34 & 46 & & Yes \\
\hline 26 & & $\mathrm{III}_{8}$ & $\mathbf{M}$ & & & & 1 & & & & & & 34 & 44 & Farm hand & Yes \\
\hline
\end{tabular}




\begin{tabular}{|c|c|c|c|c|c|c|c|c|c|c|c|c|c|c|c|c|c|}
\hline 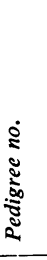 & & Uूँ & ڤัँ & $\begin{array}{l}\Xi \\
\Xi \\
\Xi \\
\Xi\end{array}$ & 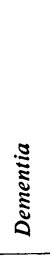 & 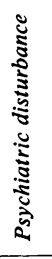 & 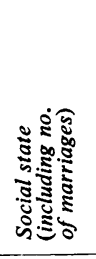 & 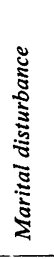 & 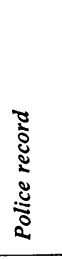 & 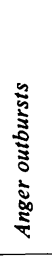 & 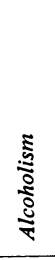 & 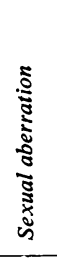 & 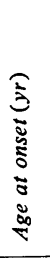 & 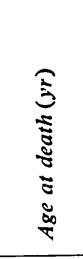 & 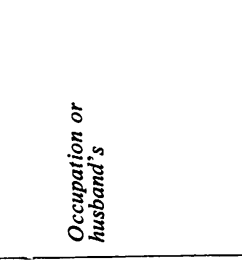 & 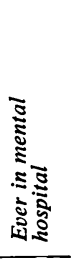 & 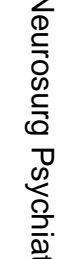 \\
\hline 26 & Sib & $\left\{\mathrm{III}_{9}\right.$ & $\mathbf{M}$ & 3 & 3 & 6 & 1 & 0 & 0 & 0 & 0 & 0 & 31 & $\begin{array}{l}>47 \\
\text { Still L }\end{array}$ & Farm hand & No & $\begin{array}{l}\text { হ } \\
\stackrel{\Rightarrow}{\Rightarrow}\end{array}$ \\
\hline 26 & Sib & $\left\{\mathrm{III}_{19}\right.$ & M & 3 & 0 & 0 & 1 & 0 & + & 0 & 0 & 0 & & 41 & Grazier & No & $\stackrel{\bar{S}}{\longrightarrow}$ \\
\hline 26 & & $\mathrm{KIII}_{24}$ & $\mathbf{M}$ & 1 & 1 & 9 & 1 & 3 & + & 3 & 3 & 0 & 37 & $\mathbf{L}$ & Grazier & No & $\overline{0}$ \\
\hline 26 & & $\mathrm{IV}_{3}$ & $\mathbf{F}$ & 2 & 0 & 0 & 1 & 0 & 0 & 0 & 0 & 0 & 30 & $\vec{L}$ & Executive & No & ᄃ \\
\hline 26 & & $\mathrm{IV}_{5}$ & $\mathbf{M}$ & 1 & 1 & 6 & 0 & 0 & + & - & - & +3 & 27 & $\overrightarrow{\mathbf{L}}$ & Fitter and turner & No & $\underline{\sigma}$ \\
\hline 26 & & $\mathrm{IV}_{6}$ & $F$ & 1 & 0 & 3 & 0 & 0 & 0 & 3 & - & 1 & 17 & $\overline{\mathbf{L}}$ & Invalid & No & $\overline{\underline{\alpha}}$ \\
\hline 27 & & $\mathrm{II}_{3}$ & $\mathbf{M}$ & $\underline{3}$ & - & 9 & 1 & & & 3 & & & & $\begin{array}{r}62 \\
59\end{array}$ & - & No & $\overrightarrow{\mathbb{D}}$ \\
\hline 27 & $\mathrm{Sib}\{$ & $\int^{\mathrm{III}_{3}}$ & $\mathbf{M}$ & - & - & 9 & 1 & - & - & - & 3 & - & - & 59 & & $\begin{array}{l}\text { No } \\
\text { Inst. }\end{array}$ & 임 \\
\hline 27 & & $\mathrm{IIII}_{5}$ & $\mathbf{F}$ & 1 & 3 & 9 & 1 & 3 & + & 3 & 3 & 3 & & 50 & Car salesman & Yes & क \\
\hline 33 & & $\mathrm{III}_{2}$ & $\mathbf{M}$ & 3 & 1 & 3 & 1 & 2 & 0 & 3 & 0 & 0 & 33 & $\begin{array}{l}>60 \\
\text { Still L }\end{array}$ & Mechanic & No & $\overrightarrow{0}$ \\
\hline $\begin{array}{l}33 \\
33\end{array}$ & & $\begin{array}{l}\mathrm{III}_{3} \\
\mathrm{III}_{7}\end{array}$ & $\begin{array}{l}\mathbf{M} \\
\mathbf{M}\end{array}$ & 3 & 1 & 3 & 1 & $\begin{array}{l}3 \\
3\end{array}$ & $\begin{array}{l}+ \\
+\end{array}$ & 3 & 0 & 0 & 31 & 42 & Painter & $\begin{array}{l}\text { No } \\
\text { No }\end{array}$ & $\overrightarrow{\vec{\omega}}$ \\
\hline 35 & Sib & $\int^{\mathrm{III}_{5}}$ & $\begin{array}{l}\mathbf{M} \\
\mathbf{M}\end{array}$ & $\begin{array}{l}3 \\
3\end{array}$ & $\begin{array}{l}1 \\
2\end{array}$ & $\begin{array}{l}3 \\
3\end{array}$ & $\begin{array}{l}1 \\
0\end{array}$ & $\begin{array}{l}3 \\
0\end{array}$ & $\stackrel{+}{0}$ & 1 & 0 & 0 & 41 & $>52$ & $\begin{array}{l}\text { Painter } \\
\text { Qld. Champion } \\
\text { weight lifter }\end{array}$ & No & o \\
\hline 35 & Siv & $\operatorname{liII}_{9}$ & $\mathbf{F}$ & 2 & 2 & 0 & 1 & 0 & 0 & 0 & 0 & 0 & 45 & $48 \mathrm{~L}$ & $\begin{array}{l}\text { weight lifter } \\
\text { Office worker }\end{array}$ & $\begin{array}{l}\text { No } \\
\text { No }\end{array}$ & కై \\
\hline 36 & & $\mathrm{II}_{5}$ & $\mathbf{M}$ & 3 & 3 & 9 & 1 & 2 & ++ & 3 & 0 & 1 & 47 & 62 & Company manager & Yes & पे \\
\hline 37 & & $I_{1}$ & M & 3 & 3 & 0 & & & & & & - & & 72 & Timber manager & No & W \\
\hline 37 & Sib & $\left\{\mathrm{II}_{2}\right.$ & $\mathbf{M}$ & 3 & 3 & 0 & 1 & & 0 & 1 & 0 & 0 & 45 & 70 & Farmer & No & a \\
\hline 37 & SIO & $\mathrm{III}_{3}$ & $F$ & 3 & 3 & 0 & 1 & 3 & & 1 & & - & 30 & 56 & Farmer & No & $v$ \\
\hline 37 & Sib & $\left\{\mathrm{III}_{10}\right.$ & $\mathbf{M}$ & 3 & 0 & 0 & 1 & 0 & 0 & 0 & 0 & 0 & 43 & L & Farmer & No & $\infty$ \\
\hline 37 & S10 & $\left\{\mathrm{IIII}_{17}\right.$ & $\mathbf{F}$ & 3 & 3 & 3 & 1 & 1 & 0 & 0 & 0 & 0 & 31 & $\mathrm{~L}$ & Mechanic & No & 0 \\
\hline 37 & & $I V_{5}$ & $\mathbf{F}$ & 3 & 0 & 0 & 0 & 0 & 0 & 0 & 0 & 0 & 30 & $\mathbf{L}$ & Switchboard operator & No & 으 \\
\hline 39 & & $I V_{1}$ & $\mathbf{M}$ & 3 & 3 & 6 & 1 & - & - & - & - & - & & 60 & & No & $\stackrel{\rho}{\rho}$ \\
\hline 39 & & $\mathrm{IV}_{3}$ & $\mathbf{F}$ & 3 & 3 & 9 & 1 & 1 & - & 3 & - & 0 & - & $\mathbf{L}$ & Mechanic & No & ஜே \\
\hline 39 & & $\mathrm{IV}_{5}$ & M & 3 & 3 & 6 & 0 & 0 & - & - & - & 0 & - & & & No & $=$ \\
\hline 39 & & $v_{3}$ & $\mathbf{M}$ & 1 & 0 & 0 & 1 & - & 0 & 1 & 0 & 0 & 31 & L & Truck driver & No & $\times \stackrel{8}{0}$ \\
\hline 42 & & $\mathrm{II}_{4}$ & $\mathbf{F}$ & 3 & 3 & 6 & 1 & 0 & 0 & 3 & 0 & 0 & 62 & 73 & Dairy farmer & No & ○ \\
\hline 42 & Sib & $\int_{\mathrm{III}_{3}}^{\mathrm{I}_{3}}$ & $\mathbf{F}$ & 3 & 3 & 6 & 1 & 0 & 0 & 2 & 0 & 0 & 44 & $\mathbf{L}$ & $\begin{array}{l}\text { Motor accessories } \\
\text { firm }\end{array}$ & $\begin{array}{l}\text { No } \\
\text { Inst. }\end{array}$ & 응 훙 \\
\hline $\begin{array}{l}42 \\
44\end{array}$ & & $\mathrm{IIII}_{5}$ & $\begin{array}{l}\mathbf{F} \\
\mathbf{M}\end{array}$ & 1 & 0 & 0 & 1 & 0 & + & 0 & 0 & 0 & 49 & $\begin{array}{c}\mathrm{L} \\
70 \text { 's }\end{array}$ & $\begin{array}{l}\text { Postman } \\
\text { Farmer }\end{array}$ & No & 을 \\
\hline $\begin{array}{l}44 \\
44\end{array}$ & & $\begin{array}{c}I_{1} \\
I_{I_{6}}\end{array}$ & $\mathrm{~F}$ & 3 & 1 & 0 & 1 & 0 & 0 & 3 & 0 & 0 & & 70 's & Farmer & No : & $\stackrel{+}{+}$ \\
\hline 44 & $\mathrm{Sib}$ & $\left\{\begin{array}{l}\mathrm{II}_{8} \\
\mathrm{~S}\end{array}\right.$ & $\mathrm{F}$ & 3 & 1 & - & 1 & 0 & 0 & - & 0 & 0 & & $\begin{array}{c}>80 \\
L\end{array}$ & & No & N \\
\hline 44 & & $\mathrm{II}_{10}$ & M & 3 & 3 & 9 & 1 & 3 & 0 & 3 & 0 & 0 & 40 & 58 & Labourer & Yes & 뭉 \\
\hline 44 & & $\mathrm{III}_{16}$ & $\mathbf{M}$ & 3 & 2 & 6 & 1 & 2 & 0 & 3 & 0 & 0 & & $\begin{array}{c}>65 \\
L\end{array}$ & - & No & ذ్ \\
\hline 44 & & $\int^{\mathrm{III}_{18}}$ & $\mathbf{F}$ & 3 & 2 & 6 & 2 & 3 & 0 & 2 & 0 & 0 & 52 & $\begin{array}{c}>62 \\
\mathrm{~L}\end{array}$ & Labourer & No & 高 \\
\hline $\begin{array}{l}44 \\
44\end{array}$ & Sib & $\mathrm{III}_{20}$ & $\mathrm{~F}$ & & & & & & & & & - & 40 & $\begin{array}{r}59 \\
\mathrm{~L}\end{array}$ & Railwayman & No & 임 \\
\hline $\begin{array}{l}44 \\
44\end{array}$ & & $\mathrm{IIII}_{24}$ & $\mathbf{M}$ & 2 & $\begin{array}{l}0 \\
0\end{array}$ & 0 & $\begin{array}{l}0 \\
2\end{array}$ & 0 & $\bar{z}$ & E & 二 & - & $\begin{array}{l}40 \\
60\end{array}$ & $\stackrel{\mathbf{L}}{\mathbf{L}}$ & $\begin{array}{l}\text { Railwayman } \\
\text { Farmer }\end{array}$ & $\begin{array}{l}\text { No } \\
\text { No }\end{array}$ & 은 \\
\hline 44 & Sib & $\left\{\begin{array}{l}\mathrm{III}_{33} \\
\mathrm{IIII}_{3}\end{array}\right.$ & $\begin{array}{l}\mathbf{F} \\
\mathbf{M}\end{array}$ & $\begin{array}{l}2 \\
2\end{array}$ & $\begin{array}{l}0 \\
0\end{array}$ & $\overline{-}$ & $\begin{array}{l}2 \\
0\end{array}$ & - & - & & & & 57 & L & Farmer & No & $\overrightarrow{\overrightarrow{0}}$ \\
\hline 44 & & $\mathrm{III}_{40}$ & $\mathbf{M}$ & 1 & 0 & 6 & 0 & 0 & 0 & 3 & 0 & 0 & 50 & $\mathbf{L}$ & Builder's labourer & No & 3 \\
\hline 44 & $\mathrm{Sib}$ & $\left\{\mathrm{III}_{42}\right.$ & $\mathbf{F}$ & 1 & 0 & 3 & 2 & 3 & 0 & 一 & - & - & 32 & $\begin{array}{c}>47 \\
\mathrm{~L}\end{array}$ & Meat worker & No & $\underset{⿱ 乛}{\stackrel{g}{\rightleftarrows}}$ \\
\hline 45 & & $\mathrm{II}_{2}$ & M & - & - & - & 1 & & & & & & 45 & 69 & Grazier & $\begin{array}{l}\text { No } \\
\text { Inst. }\end{array}$ & 兑 \\
\hline 45 & & $\mathrm{III}_{8}$ & $\begin{array}{l}\mathbf{F} \\
F\end{array}$ & 1 & 1 & 0 & 1 & 3 & + & 2 & 0 & 0 & 40 & $\mathbf{L}$ & Waitress & No & $\overline{2}$ \\
\hline $\begin{array}{l}46 \\
46\end{array}$ & & $\begin{array}{c}\mathbf{I}_{2} \\
\mathbf{I I}_{2}\end{array}$ & $\begin{array}{l}F \\
F\end{array}$ & - & 一 & - & - & - & - & $\overline{-}$ & $\overline{-}$ & $\overline{-}$ & - & $\begin{array}{l}57 \\
62\end{array}$ & & No & 뭄 \\
\hline 46 & $\mathrm{Sib}$ & $\left\{\begin{array}{l}\mathbf{I I}_{2} \\
\mathbf{I I}_{8}\end{array}\right.$ & $\begin{array}{l}\mathbf{F} \\
\mathbf{F}\end{array}$ & - & $\overline{-}$ & $=$ & $\bar{z}$ & $\bar{z}$ & 二 & E & $\bar{z}$ & - & 二 & $\begin{array}{l}62 \\
76\end{array}$ & - & No & $\frac{\sigma}{3}$ \\
\hline 46 & & $\left\{\begin{array}{l}\Pi_{8} \\
I_{11}\end{array}\right.$ & $\mathbf{F}$ & 二 & 二 & $\overline{-}$ & 二 & - & 二 & 二 & 二 & - & - & 72 & - & No & \\
\hline 47 & & $\mathrm{II}_{2}$ & $\mathbf{F}$ & 3 & 3 & 3 & 1 & 0 & 0 & 2 & 0 & 0 & - & c64 & Miner & $\begin{array}{l}\text { No } \\
\text { Inst. }\end{array}$ & 을 \\
\hline 47 & & $\mathrm{III}_{5}$ & M & 3 & 0 & 9 & - & - & + & - & - & - & - & 40 & & No & $\frac{1}{2}$ \\
\hline 47 & & $\mathrm{III}_{7}$ & $\mathbf{M}$ & 3 & 3 & 9 & 1 & 2 & - & 3 & 一 & 1 & $\begin{array}{l}41 \\
27\end{array}$ & $\begin{array}{l}58 \\
41\end{array}$ & Mill worker & No & 윽 \\
\hline 47 & Sib & $\mathrm{III}_{15}$ & $\mathbf{M}$ & 3 & 3 & 6 & 0 & 0 & $\overline{0}$ & 3 & $\overline{0}$ & $\overline{0}$ & $\begin{array}{l}27 \\
51\end{array}$ & $\begin{array}{l}41 \\
71\end{array}$ & $\begin{array}{l}\text { Bore worker } \\
\text { Executive }\end{array}$ & $\begin{array}{l}\text { Yes } \\
\text { No }\end{array}$ & $D$ \\
\hline 47 & 010 & $\mathrm{III}_{17}$ & $\mathbf{F}$ & 3 & 1 & 0 & 1 & 0 & & & & & & & & Inst. & 윽. \\
\hline 47 & & $\mathrm{IIII}_{20}$ & $\mathbf{M}$ & 3 & 0 & 0 & 1 & 0 & 0 & 2 & 0 & 0 & 40 & 66 & Motor mechanic & No & \\
\hline
\end{tabular}




\begin{tabular}{|c|c|c|c|c|c|c|c|c|c|c|c|c|c|c|c|}
\hline 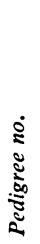 & है & ڤัँ & 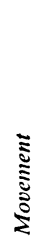 & 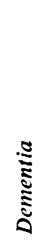 & 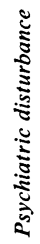 & 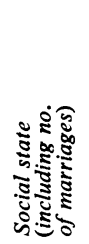 & 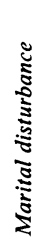 & 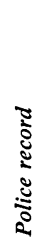 & 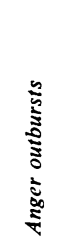 & $\begin{array}{l}\frac{\pi}{3} \\
\frac{5}{0} \\
\frac{0}{\pi} \\
\end{array}$ & 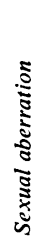 & 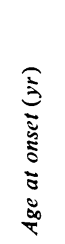 & 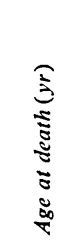 & 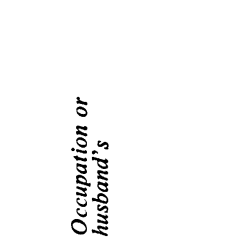 & 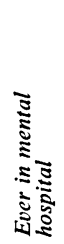 \\
\hline 47 & $\mathrm{III}_{18}$ & $\mathbf{M}$ & 3 & 3 & 6 & 1 & 2 & - & 3 & 3 & - & 40 & 61 & Wharf labourer & No \\
\hline 47 & $\operatorname{Sib}\left\{\mathrm{IV}_{3}\right.$ & $\mathbf{M}$ & 2 & 1 & 8 & 1 & 3 & + & 3 & 3 & 0 & 30 & $\begin{array}{r}>57 \\
\text { L }\end{array}$ & Shop manager & Yes \\
\hline 47 & $\mathrm{IV}_{6}$ & $\mathbf{F}$ & 1 & 1 & 6 & 1 & - & 0 & 3 & - & - & 57 & $\bar{L}$ & Company manager & No \\
\hline 47 & $\mathrm{IV}_{13}$ & $\mathbf{M}$ & 3 & 3 & 6 & 1 & 0 & + & 3 & 0 & 0 & 28 & 58 & Timber works owner & Yes \\
\hline 47 & $\operatorname{Sip}_{\mathrm{Iin}} \mathrm{IV}_{15}$ & $\mathbf{M}$ & 3 & 3 & 6 & 1 & 0 & 0 & 0 & 0 & 0 & 31 & 53 & Timber worker & No \\
\hline 47 & $\operatorname{Sib}\left\{\mathrm{IV}_{18}\right.$ & $\mathbf{F}$ & & & & & & & & & & & $c 57$ & $\begin{array}{l}\text { Owner of motor } \\
\text { garage }\end{array}$ & No \\
\hline 47 & $\mathrm{IV}_{24}$ & $\mathbf{M}$ & 1 & 1 & 0 & 1 & 1 & 0 & 2 & 0 & 0 & 49 & L & Draughtsman & No \\
\hline 47 & $\mathrm{IV}_{30}$ & $\mathbf{F}$ & 1 & 0 & 3 & 1 & 0 & - & - & - & 0 & 46 & & Timber owner & No \\
\hline 47 & $v_{9}$ & $\mathrm{~F}$ & 1 & 0 & 0 & 1 & 0 & - & 0 & 0 & 0 & 30 & & & \\
\hline 50 & $\mathrm{IV}_{3}$ & $\mathbf{F}$ & 3 & 1 & 1 & 1 & 0 & 0 & $1 \frac{1}{2}$ & 0 & 0 & 38 & 58 & Builder & $\begin{array}{l}\text { No } \\
\text { Inst. }\end{array}$ \\
\hline 51 & $\mathrm{III}_{8}$ & $\mathbf{M}$ & 3 & 2 & 1 & 1 & 0 & 0 & 1 & 0 & 0 & 24 & 42 & SGIO & $\begin{array}{l}\text { No } \\
\text { Inst. }\end{array}$ \\
\hline 53 & $\mathrm{II}_{9}$ & $\mathbf{F}$ & 3 & 1 & 0 & 1 & 0 & 0 & 0 & & 1 & 50 & 73 & Wharfie & No \\
\hline 53 & $\operatorname{Sib}\left\{\mathrm{III}_{6}\right.$ & $\mathbf{M}$ & 3 & - & - & 0 & - & - & - & - & - & - & 40 & - & Yes \\
\hline 53 & ${ }^{\mathrm{SIO}}\left\{\mathrm{III}_{8}\right.$ & $\mathbf{M}$ & 3 & & & 0 & - & & & & & & 58 & - & No \\
\hline 53 & $\mathrm{III}_{26}$ & $\mathbf{F}$ & 3 & 1 & 0 & 1 & - & & - & - & - & 55 & 73 & Wharfie & No \\
\hline 53 & $\mathrm{III}_{30}$ & $\mathrm{~F}$ & 3 & 2 & 0 & 1 & 0 & 0 & 0 & 0 & 0 & 45 & 59 & Vaudeville & No \\
\hline 53 & $\mathrm{IV}_{5}$ & $\mathrm{~F}$ & 1 & 1 & 0 & 1 & 2 & 0 & 0 & 0 & 0 & 36 & $\mathrm{~L}$ & Labourer & No \\
\hline 53 & $I_{49}$ & M & 3 & 1 & $\mathbf{0}$ & 1 & 3 & - & - & - & 0 & 23 & 62 & Labourer & No \\
\hline 53 & $\mathrm{IV}_{65}$ & $\mathrm{~F}$ & 3 & 1 & 0 & 1 & 3 & + & 0 & - & 3 & 21 & $\mathrm{~L}$ & Labourer & No \\
\hline 53 & $\mathrm{IV}_{65}$ & M & 3 & 3 & 0 & 0 & 0 & + & 0 & - & - & 18 & 31 & Theatre projector & No \\
\hline 53 & Sib $\left\{I_{70}\right.$ & $\mathrm{F}$ & 2 & 1 & 2 & 1 & 2 & + & 0 & 0 & 0 & 29 & $\mathrm{~L}$ & Labourer & No \\
\hline 53 & $\operatorname{IV}_{71}$ & $\mathbf{M}$ & 3 & 3 & 3 & 0 & 0 & 0 & 0 & 3 & 0 & 19 & 32 & Labourer & Yes \\
\hline 53 & $v_{5}$ & $\mathbf{M}$ & 0 & 0 & 0 & 0 & 0 & 0 & 0 & 1 & 0 & 20 & L & Labourer & No \\
\hline 53 & $V_{78}$ & $\mathrm{~F}$ & 0 & 0 & 0 & 1 & 0 & 0 & 0 & 0 & $\mathbf{0}$ & 19 & $\bar{L}$ & Labourer & No \\
\hline 55 & $\mathrm{III}_{5}$ & M & 3 & 3 & 9 & 1 & 3 & + & 3 & 3 & 1 & $40 ?$ & $\vec{L}$ & Anthropologist & No \\
\hline 78 & $\mathrm{II}_{2}$ & $\mathbf{M}$ & 3 & 0 & 0 & 1 & 0 & 0 & 1 & 0 & 0 & 50 & 76 & Farmer & No \\
\hline 78 & $\mathrm{III}_{2}$ & $\mathbf{M}$ & 2 & 2 & 0 & 1 & 0 & 0 & 0 & 0 & 0 & 39 & 57 & Farmer & No \\
\hline 80 & $I_{1}$ & $\mathrm{~F}$ & 3 & 3 & & 1 & & & & & & 46 & 64 & Farmer & $\begin{array}{l}\text { No } \\
\text { Inst. }\end{array}$ \\
\hline 80 & $\mathrm{II}_{2}$ & M & 3 & & & 1 & & & & & & 50 & 64 & & \\
\hline 80 & $\operatorname{Sin} \int \mathrm{II}_{5}$ & $\mathbf{F}$ & 1 & 0 & 0 & 1 & 0 & & & & & 60 & L & - & No \\
\hline 80 & 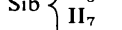 & $\mathrm{F}$ & 3 & 2 & 6 & 1 & 0 & 0 & 3 & - & - & 50 & $\mathrm{~L}$ & - & No \\
\hline 80 & $I I I_{9}$ & M & 1 & 0 & 0 & $i$ & 0 & 0 & & & & 54 & L & Farmer & No \\
\hline 81 & $\mathrm{II}_{5}$ & M & 3 & 1 & 9 & 0 & 0 & + & 3 & - & 0 & 32 & L & Labourer & Yes \\
\hline 82 & $\mathbf{I}_{1}$ & M & 3 & 3 & - & 一 & - & - & - & 0 & - & - & - & Wheelwright & No \\
\hline 82 & $\mathrm{II}_{2}$ & $\mathrm{~F}$ & 3 & 3 & 6 & 1 & 0 & - & 3 & 0 & 0 & 30 & 58 & Miner & No. \\
\hline 82 & Sip $\begin{cases}\mathrm{II}_{4} \\
\end{cases}$ & $\mathrm{F}$ & - & - & - & - & - & - & - & - & - & 50 & 76 & - & No \\
\hline 82 & $\mathrm{II}_{6}$ & $\mathbf{F}$ & 3 & 3 & 6 & 1 & 3 & 0 & $3++$ & 0 & 0 & 35 & 65 & Separated & $\begin{array}{l}\text { Inst. } \\
\text { Yes }\end{array}$ \\
\hline 82 & $\mathrm{II}_{11}$ & M & 3 & 3 & 9 & 1 & 2 & + & 3 & 0 & 0 & & & $\begin{array}{l}\text { Moving from job } \\
\text { to job }\end{array}$ & Yes \\
\hline 82 & $\mathrm{III}_{1}$ & $\mathbf{M}$ & 3 & 3 & 9 & 1 & 3 & 0 & 3 & 2 & 0 & 20 & 58 & Schoolmaster & No \\
\hline 82 & $\left\{\mathrm{III}_{5}\right.$ & $\mathrm{F}$ & 2 & 0 & 3 & 1 & 0 & 0 & 2 & 0 & 0 & 57 & L & Builder & $\begin{array}{l}\text { Inst. } \\
\text { No }\end{array}$ \\
\hline 82 & $\mathrm{III}_{7}$ & $\mathrm{~F}$ & 3 & 3 & 9 & 0 & - & 0 & 3 & 0 & 1 & 27 & $\vec{L}$ & None & Yes \\
\hline 82 & $\mathrm{IV}_{4}$ & $\mathrm{~F}$ & 2 & 2 & 0 & 1 & - & 0 & 一 & 0 & 0 & 31 & $\vec{L}$ & & No \\
\hline 82 & $\mathrm{IV}_{5}$ & $\mathbf{M}$ & 1 & 0 & 3 & 1 & - & 0 & - & 0 & 0 & 33 & $\vec{L}$ & Carpenter & No \\
\hline 83 & $\mathrm{II}_{1}$ & $\mathbf{M}$ & 3 & 3 & 9 & 1 & 2 & + & 3 & 0 & 0 & c40 & 61 & Clerk & No \\
\hline 84 & $\mathbf{I}_{3}$ & $\mathrm{~F}$ & 3 & 3 & 3 & 2 & 0 & 0 & 0 & 0 & 1 & 32 & 73 & Labourer & No \\
\hline 84 & $\mathrm{II}_{1}$ & $\mathbf{M}$ & 3 & 3 & 9 & 1 & 3 & + & 3 & 3 & + & 48 & 61 & Labourer & Yes \\
\hline 84 & $\operatorname{Sib}\left\{I_{6}\right.$ & M & 3 & 0 & 0 & 1 & 0 & 0 & 0 & 0 & 0 & 46 & 50 & Labourer & Yes \\
\hline 84 & $\mathrm{II}_{8}$ & $\mathbf{F}$ & 1 & 0 & 6 & 2 & 3 & 0 & 1 & 3 & 3 & 48 & L & Mill worker & No \\
\hline 87 & $\mathrm{II}_{8}$ & $\mathrm{~F}$ & 3 & 3 & 9 & 1 & 1 & 0 & 1 & 0 & 0 & c45 & c68 & Mill worker & No \\
\hline 87 & III & $\mathrm{F}$ & 2 & 2 & 5 & 1 & 3 & 0 & - & - & 3 & - & $\begin{array}{c}>64 \\
\mathrm{~L}\end{array}$ & Labourer & No \\
\hline 87 & $\mathrm{III}_{22}$ & $\mathbf{F}$ & 3 & 2 & 9 & 2 & 3 & 0 & 3 & 0 & 1 & 38 & $\mathbf{L}$ & Farmer & No \\
\hline 87 & $\mathrm{III}_{28}$ & $\mathrm{~F}$ & 3 & 3 & 9 & 2 & 3 & 0 & 3 & 0 & 1 & 27 & 55 & Company manager & No \\
\hline 87 & $\mathrm{Sib}\left\{\mathrm{III}_{30}\right.$ & $\mathbf{M}$ & 3 & 3 & 9 & 1 & 3 & 0 & 3 & 3 & 3 & 37 & L & Cane cutter & Yes \\
\hline 87 & $\mathrm{III}_{36}$ & $\mathbf{F}$ & 3 & 3 & 3 & 1 & 2 & 0 & 1 & 0 & 2 & 35 & $\bar{L}$ & Labourer & No \\
\hline
\end{tabular}




\begin{tabular}{|c|c|c|c|c|c|c|c|c|c|c|c|c|c|c|}
\hline 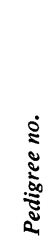 & uั & ڤ̆ & 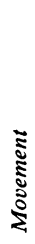 & 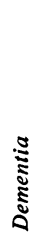 & 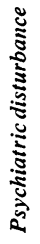 & 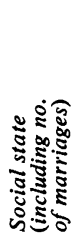 & 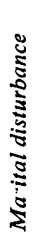 & 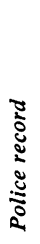 & 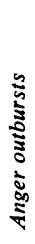 & 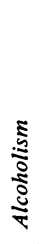 & 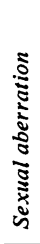 & 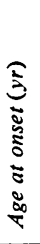 & 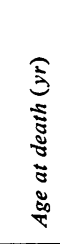 & 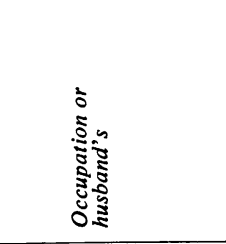 \\
\hline 87 & Sib $\left\{\right.$ III $_{44}$ & $\mathbf{F}$ & 1 & 1 & 3 & 1 & 2 & 0 & 2 & 0 & 0 & 44 & $\mathbf{L}$ & Truck driver class IV \\
\hline 87 & $I_{14}$ & $\mathbf{F}$ & 1 & 1 & 0 & 1 & 3 & $\mathbf{0}$ & 0 & 0 & 0 & 39 & $\tilde{L}$ & Labourer \\
\hline 87 & $\mathrm{IV}_{18}^{18}$ & $\mathbf{M}$ & 1 & 0 & 4 & 1 & 2 & + & 3 & 3 & 1 & 31 & $\mathbf{L}$ & Labourer \\
\hline 87 & $\mathrm{IV}_{38}$ & M & 1 & 0 & 0 & i & 0 & 0 & 0 & 0 & 0 & 27 & $\mathbf{L}$ & Truck driver \\
\hline 89 & $\mathrm{II}_{8}$ & $\mathbf{M}$ & - & - & - & - & - & - & - & - & - & 60 & 72 & \\
\hline 89 & $\mathrm{III}_{2}$ & $\mathrm{~F}$ & 3 & 3 & 3 & 1 & 2 & 一 & 2 & 0 & 0 & 44 & $\begin{array}{r}>60 \\
\text { L }\end{array}$ & Executive \\
\hline 90 & $\mathbf{I I}_{8}$ & $\mathbf{M}$ & 3 & 0 & 0 & 1 & 0 & 0 & 2 & 0 & 0 & 55 & $\begin{array}{r}>72 \\
L\end{array}$ & \\
\hline 91 & $\mathbf{I I}_{2}$ & $\mathbf{F}$ & 3 & 3 & 9 & 1 & 3 & 0 & 3 & 0 & 0 & 40 & $\begin{array}{c}>52 \\
L\end{array}$ & Labourer \\
\hline 91 & $\mathrm{III}_{2}$ & $\mathbf{F}$ & 1 & 1 & 7 & 1 & 2 & 0 & 3 & 0 & 0 & 32 & $\begin{array}{r}>34 \\
L\end{array}$ & Truck driver \\
\hline 92 & $\mathrm{II}_{9}$ & $\mathbf{F}$ & 3 & 0 & 0 & 1 & 3 & 0 & 0 & 0 & 1 & 29 & 49 & \\
\hline 92 & $\mathrm{III}_{9}$ & $\mathbf{F}$ & 3 & & & & & & & & & 13 & 33 & \\
\hline $\begin{array}{l}95 \\
95\end{array}$ & $\mathrm{II}_{\mathbf{1}}$ & $\mathbf{M}$ & 3 & 1 & 6 & 1 & 1 & 0 & 2 & 0 & 0 & 60 & $>67$ & Carpenter \\
\hline 95 & $\mathrm{III}_{3}$ & $\mathbf{F}$ & 1 & $\mathbf{0}$ & 3 & 1 & 3 & 0 & 2 & $\mathbf{0}$ & $\mathbf{0}$ & 32 & $\mathbf{L}$ & Mechanic \\
\hline 101 & $\mathrm{II}_{13}$ & F & 3 & 1 & 0 & 1 & 3 & 0 & 0 & 0 & 0 & 32 & $\mathbf{L}$ & \\
\hline 107 & $\mathrm{II}_{3}$ & $\mathrm{~F}$ & 3 & 3 & 3 & 1 & 1 & 0 & 2 & 0 & 0 & 52 & 53 & Accountant \\
\hline 107 & $\mathrm{III}_{4}$ & $\mathrm{~F}$ & 3 & 0 & 0 & 1 & 0 & 0 & 0 & 0 & 0 & 49 & 67 & Cane cutter \\
\hline 113 & $\mathrm{II}_{3}$ & $\mathbf{F}$ & 3 & 2 & 6 & 1 & - & - & 一 & - & - & 45 & $\mathbf{L}$ & Carpenter \\
\hline 117 & $\mathrm{II}_{\mathbf{1}}$ & M & 3 & 3 & 9 & 1 & 3 & 0 & 3 & 2 & 0 & 42 & 61 & School-teacher \\
\hline 117 & $\mathrm{III}_{2}$ & $\mathbf{M}$ & 3 & 1 & 9 & 1 & 3 & 0 & 3 & 3 & 0 & 31 & $\begin{array}{r}>40 \\
L\end{array}$ & Sheet metal worker \\
\hline
\end{tabular}

